\title{
Cold snare piecemeal resection of a large ampullary adenoma
}

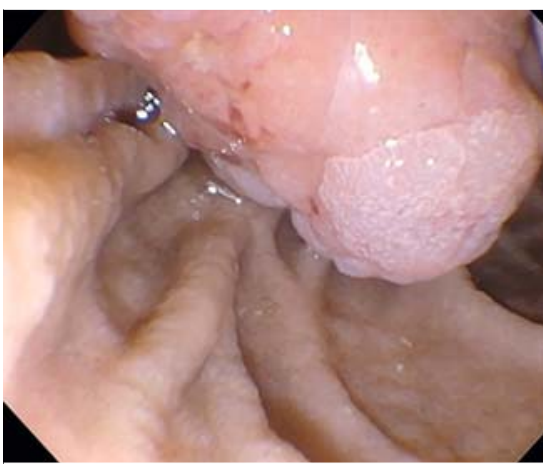

- Fig. 1 Ampullary adenoma.

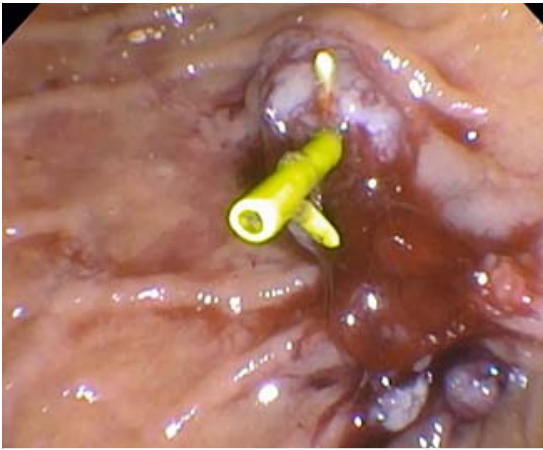

Fig. 2 Ampullary mass following cold resection and stent placement.

We describe the case of a 63-year-old patient with end-stage renal disease who underwent endoscopic ampullectomy of a large ampullary adenoma.

A side-viewing duodenoscope was utilized to evaluate the mass. A large frondlike villous mass, $40 \mathrm{~mm}$ in diameter, was seen at the major papilla ( $\mathbf{F i g . 1}$ ). The mass was resected using a dedicated thin-wire braided snare (cold snare) in a piecemeal fashion, and retrieved with a retrieval net ( $\triangleright$ Video $\mathbf{1})$. The snare deformed with repeated use and a total of four snares were required to complete the procedure.

Following resection, the ventral pancreatic duct was deeply cannulated with a short-nosed traction sphincterotome and guidewire. There was no extension of the polyp into the pancreatic duct,

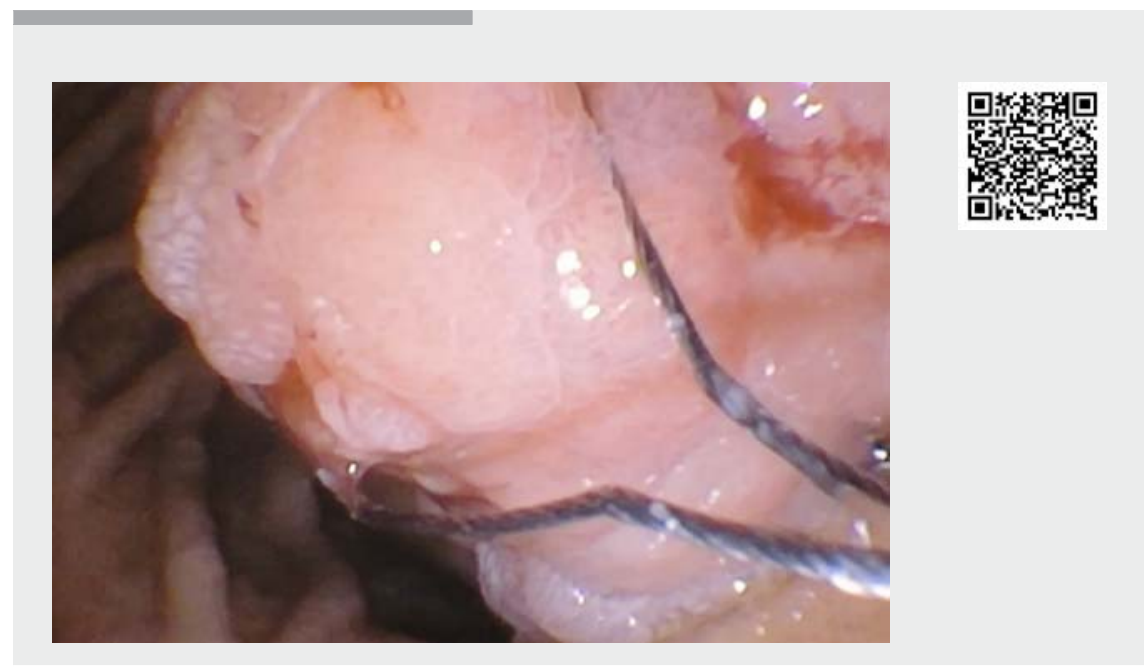

Video 1 Cold snare piecemeal resection of a large ampullary adenoma.

and a temporary plastic stent was placed ( Fig.2). The patient tolerated the procedure without immediate complications. Pathology from the specimen revealed adenoma with high-grade dysplasia.

Endoscopic ampullectomy is a safe and successful alternative to surgery for removal of selected ampullary adenomas. Recent studies have suggested that ampullary adenomas may be endoscopically removed either piecemeal or en bloc using electrocautery [1]. A recent study in Japan evaluated 136 patients with laterally spreading ampullary adenomas [2]. A single treatment session was possible in 104 (83.2\%) of the 125 patients in the en bloc resection group and in 8 $(72.7 \%)$ of the 11 in the piecemeal resection group. The total resection rate including additional treatments was $98.4 \%$ in the en bloc group and $100 \%$ in the piecemeal group. This suggests that piecemeal resection using electrocautery is comparable to en bloc resection. Cold snare resection of colonic polyps is gaining acceptance and there are reports of cold snare removal of large polyps [3]. To our knowledge this is the first case to date of successful cold snare ampullectomy in a patient at high risk for postprocedural bleeding.

Endoscopy_UCTN_Code_TTT_1AR_2AK

\section{Competing interests}

The authors declare that they have no conflict of interest.

The authors

Rahman Nakshabendi, Theodore W. James, Todd Huntley Baron

Division of Gastroenterology and Hepatology, University of North Carolina, Chapel Hill, North Carolina, United States

\section{Corresponding author}

\section{Rahman Nakshabendi, MD}

Division of Gastroenterology and Hepatology, University of North Carolina System-Medicine, 101 Manning Drive, Chapel Hill, NC 27514-3916, United States Fax: +1-984-974-5050

Rnakshabendi@unc.edu 


\section{References}

[1] Panzeri F, Crippa S, Castelli P et al. Management of ampullary neoplasms: a tailored approach between endoscopy and surgery. World J Gastroenterol 2015; 21: 7970-7987

[2] Yamamoto K, Sofuni A, Tsuchiya T et al. Clinical impact of piecemeal resection concerning the lateral spread of ampullary adenomas. Intern Med 2019; 58: 901-906

[3] Tate D], Awadie H, Bahin FF et al. Wide-field piecemeal cold snare polypectomy of large sessile serrated polyps without a submucosal injection is safe. Endoscopy 2018; 50: 248-252

\section{Bibliography}

Endoscopy 2021; 53: E3-E4

DOI 10.1055/a-1167-7834

ISSN 0013-726X

published online 19.5.2020

(c) 2020. Thieme. All rights reserved.

Georg Thieme Verlag KG, Rüdigerstraße 14

70469 Stuttgart, Germany

\section{ENDOSCOPY E-VIDEOS}

https://eref.thieme.de/e-videos

回回 Endoscopy E-Videos is a free access online section, reporting 回: on interesting cases and new techniques in gastroenterological endoscopy. All papers include a high quality video and all contributions are freely accessible online.

This section has its own submission website at

https://mc.manuscriptcentral.com/e-videos 